\title{
3 Research Soure \\ Fractionation of Organic C, Nutrients, Metals And Bacteria In Peat Porewater And Ice After Freezing And Thawing
}

Sergey Yu. Morgalev

Tomsk State University

Artem G. Lim

Tomsk State University

Tamara G. Morgaleva

Tomsk State University

Yuri N. Morgalev

Tomsk State University

Rinat M. Manasypov

Tomsk State University

Daria Kuzmina

Tomsk State University

Liudmila S. Shirokova

University of Toulouse

Laurent Orgogozo

University of Toulouse

Sergey V. Loiko

Tomsk State University

Oleg S. Pokrovsky (D Oleg.POKROVSKY@Get.omp.eu )

University of Toulouse https://orcid.org/0000-0002-3155-7069

\section{Research Article}

Keywords: peat, pore water, freezing, thawing, major, trace elements, nutrients, toxicants, microorganisms

Posted Date: January 28th, 2022

DOI: https://doi.org/10.21203/rs.3.rs-1182151/v1

License: (1) (1) This work is licensed under a Creative Commons Attribution 4.0 International License.

Read Full License 


\section{Abstract}

To better understand freezing - thawing cycles operating in peat soils of permafrost landscapes, we experimentally modelled bi-directional freezing and thawing of the three sections of $90-\mathrm{cm}$ long peat core collected from a discontinuous permafrost zone in western Siberia. We measured translocation of microorganisms and changes in porewater chemistry $(\mathrm{pH}, \mathrm{UV}$ absorbance, dissolved organic carbon (DOC), and major and trace element concentrations) after thawing and two-way freezing of peat cores. We demonstrate that bi-directional freezing and thawing of a peat core is capable of strongly modifying the vertical pattern of bacteria, DOC, nutrients, and trace element concentrations. Sizeable enrichment (a factor of 2 to 5) of DOC, macro- (P, K, Ca) and micro-nutrients ( $\mathrm{Ni}, \mathrm{Mn}, \mathrm{Co}, \mathrm{Rb}, \mathrm{B}$ ) and some low-mobile trace elements in several horizons of ice and peat porewater after freeze/thaw experiment may stem from physical disintegration of peat particles, leaching of peat constituents and opening of isolated (nonconnected) pores during freezing front migration. However, due to the appearance of multiple maxima of element concentration after a freeze-thaw event, the use of peat ice chemical composition as environmental archive for paleo-reconstructions is unwarranted.

\section{Introduction}

The change of seasonal thawing-freezing regime in the Arctic regions due to climate warming is an issue of large concern for many aspects of climate modelling and soil ecosystem services (Henry, 2008). In permafrost regions, the most pronounced soil thaw occurs where soil temperature fluctuates around $0^{\circ} \mathrm{C}$ (Romanovsky et al., 2010) and corresponds to discontinuous and sporadic permafrost zones. Ongoing climate warming is likely to increase the frequency of freeze-thaw cycles (FTC) in both aquatic and soil settings of permafrost regions (Henry, 2008; Hayashi et al., 2013). Such cycles may be especially important in controlling the $\mathrm{DOC}$ and element concentration in permafrost peatlands due to the high concentration of dissolved organic carbon (DOC) in both peat porewaters (Reeve et al., 1996; Raudina et al., 2017) and surface waters (Ma et al., 2019; Pokrovsky et al., 2020). However, at high DOC concentration of peat porewater, the organic and organo-mineral solutes and colloids are more likely to coagulate compared to that of lakes and rivers.

FTC are capable of affecting physical and hydraulic properties, greenhouse gas emissions, geochemical processes and microbial communities in mineral soils (Hayashi, 2013). Over past decades, a sizable number of works have been devoted to characterizing the impact of freezing and thawing on mineral soil properties (DeLuca et al., 1992; Kim et al., 2017; Larsen et al., 2002; Fitzhugh et al., 2003; Ren and Vanapalli, 2020; Schimel and Clein, 1996; Vestgarden and Austnes, 2009; Xiao et al., 2019). However, the implications of FTC on hydrochemical composition of peat porewater and ice have not been well described (McCarter et al., 2020) given that the majority of available studies deal with the physical and hydrological parameters of peat (e.g., Nagare et al., 2012; Smerdon and Mendoza, 2010).

Unlike field observations that incorporate multiple parameters capable of impacting transformation of solutes over the soil column, laboratory experiments allow for more rigorous assessment of governing 
factors and quantification of freezing/thawing effects (Schwamborn et al., 2012; Chen et al., 2016; Spencer et al., 2017; Jiang et al., 2018; Kim and Choi, 2018; Chung et al., 2020; Savenko et al., 2020). Previously, we demonstrated the existence of strong peak of bacterial metabolic activity at the border between frozen and thawed layers (Morgalev et al., 2017) of a peat core collected in the Western Siberian Lowland. This peak was explained by freezing front migration and concentration of nutrients and certain groups of microorganisms at the bottom of the active layer. Forced translocation of microorganisms via freezing front migration has been evidenced in laboratory experiments on aqueous suspension (Morgalev et al., 2019). In peat cores for all permafrost zones in western Siberia, a strong local maximum of DOC, $P$, $\mathrm{Ca}$, Fe and other trace element concentrations was recently found in ice sampled below the current active layer boundary (Lim et al., 2021). Such an enrichment at $90 \pm 10 \mathrm{~cm}$ depth was presumably formed by the freezing of the soil column from both the surface and the bottom resulting in a combined mid-point freezing process that would thereby concentrate solutes.

Experimental assessments on the effect of bi-directional (from upper and bottom part of the core) freezing of soils from permafrost regions are very scarce, and more so for organic (peat-rich) soils (Nagare et al., 2012 a, b). However, these essentially physical studies did not address the chemical and microbiological aspects during peat freezing processes. There are several physico-chemical mechanisms capable of modifying the concentration pattern of bacteria and solutes across the peat core. First, the mechanical removal of bacteria, DOC and chemical elements from the upper part of the porous peat by a downward moving freezing front and their deposition at the upper front (a layer of seasonal freezing) and bottom (permafrost) layer boundary. This process was revealed to be essential in formation of carbonand trace element enriched layers in dispersed peat ice across the permafrost gradient in western Siberia (Lim et al., 2021). Second, thawing of the previously frozen part of the peat core may lead to $I$ ) leaching of peat organic and inorganic constituents to aqueous solution, ii) disintegration of peat grains and production of large size colloids, and iii) opening of isolated (non-connected) pores that contain solutes and bacteria. These mechanisms are likely to operate over full depth of the peat column and capable of enriching the peat porewater and ice in organic and inorganic solutes and bacteria. Third, during freezing front migration, there could be occlusion of aquatic components into ice structure. This process is somewhat similar to cryoturbation and inclusion of surface organic components into the deeper mineral horizons of soils.

In this work, we quantified the changes in bacterial cells, DOC, major and trace inorganic solutes concentration induced by experimental freezing and thawing of peat cores and compared the concentration patterns with those of natural cores from a permafrost peatland. The global applications of this work are to $i$ ) foresee possible consequences of freeze-thaw processes and active layer thickness (ALT) increase for carbon, nutrient and metal release from peat soil to surface waters and ii) verify whether chemical composition of peat porewater and ice can be used as an environmental archive.

\section{Materials And Methods}

\subsection{Permafrost peat core sampling}


Peat core samples were collected on August 5th, 2017 in the palsa peat bog of the discontinuous permafrost zone in the northern part of the western Siberian Lowland. The site is within the Khanymey Research Station of the INTERACT (N 63 $43^{\prime} 19.73^{\prime \prime}$ E $75^{\circ} 57^{\prime} 47.91^{\prime \prime}$ ) located in the flat hilly peatland of the forest-tundra biome. The mean annual air temperature is $-5.6^{\circ} \mathrm{C}$ and the annual precipitation is $540 \mathrm{~mm}$. The dominant soil catenae are flat-mound bogs along watershed divides. The Hemic Cryic Histosols are developed on peat mounds. There, peat (1.0-1.5 m thick) overlays the sand with minor amounts of clay and silt. The mounds ( $50 \pm 20 \%$ of total palsa area) and depressions are less than $1 \mathrm{~m}$ in diameter; depths of the depressions range between 40 and $50 \mathrm{~cm}$. The average thickness of the active layer is $41 \pm 5 \mathrm{~cm}$ at the mounds and >1-1.5 $\mathrm{m}$ in the depressions. The peat is essentially composed of Sphagnum rubellum, lichens (Cladonia stellaris), dwarf shrubs, green mosses, pine wood and pine and birch bark as described in detail in previous studies (Morgalev et al., 2017).

Peat core was extracted from the frozen mound using a motorized Russian peat corer (UKB-12/25 I, Russia) with a 4-cm diameter corer sterilized with $40 \%$ ethanol prior to each extraction. The samples were kept at $-20^{\circ} \mathrm{C}$ during transport and storage. To collect peat ice, the frozen peat core was cut using a ceramic blade into $10-\mathrm{cm}$ layers, and thawed at room temperature. Immediately after full thawing of the frozen core, peat water was extracted through $100-\mu \mathrm{m}$ pre-cleaned Nylon net by applying a local confining pressure (1-5 $\mathrm{kg} \mathrm{cm}^{-2}$, depending on sample humidity). The obtained slurry was centrifuged for $15 \mathrm{~min}$ at $3500 \mathrm{rpm}$ and the supernatant was immediately filtered through $0.45 \mu \mathrm{m}$ acetate cellulose filter with the first $10 \mathrm{ml}$ of filtrate discarded. The water from the thawed part of the peat core, above the permafrost table, was extracted using the same method but in the field and immediately after peat sampling. The chemical composition of field-extracted peat water and ice was compared with that obtained from the peat core after laboratory freezing and thawing as described below.

\subsection{Freeze-thaw experiments (FTE)}

The intact peat core (15-90 cm depth) was used for freeze-thaw cycle. Note that the upper 0-15 cm of peat was saturated with water and thus not suitable for transportation and handling. Parts of the core (15-50 cm, corresponding to the active layer, and two sections of frozen peat at $50-70 \mathrm{~cm}$ and $70-95 \mathrm{~cm}$ depth) were placed in transparent PVC cylinders in the temperature-controlled climate chamber (MIR-154, Russia) and oriented vertically, similar to their field orientation. The reason of using several sections of the whole peat core is because the height of the chamber did not allow running the whole peat core (15$90 \mathrm{~cm}$ ) as one single column.

The three parts of the core thus can be considered as replicates for studying the same main process: migration of solutes within the peat column due to bi-directional freezing. Note that inevitable natural variability of peat composition, texture and water content in cores sampled within the same mound or adjacent mounds would not allow collecting identical field replicates for further laboratory experiments. Therefore, to assess the true repeatability of freezing phenomena, we design additional experiments on a $50-\mathrm{cm}$ long artificial peat cores constructed from a single homogeneous batch of peat collected in the active layer of the discontinuous permafrost zone. For this, the peat was homogenized, wetted with MilliQ water to the normal water content of natural cores, and placed in three identical columns that were frozen 
and thawed in parallel thus providing conventional experimental triplicates. In these artificial replicates, only limited number of solute parameters $\left(\mathrm{pH}\right.$, specific conductivity for total solute content, and $\mathrm{UV}_{254 \mathrm{~nm}}$ absorbance as a surrogate for terrestrial DOC in peat porewater) were measured (see section 2.3 below).

The PVC cylinders filled by native peat core or 'artificial' homogenized peat were insulated from the external lateral sides with a $5-\mathrm{cm}$ foam rubber layer; additional insulation was applied to the very bottom of the core. Cores were first allowed to thaw for $24 \mathrm{~h}$ at $22^{\circ} \mathrm{C}$. The thawing front moved from the top to the bottom as the bottom was in contact with cooling elements $\left(-16^{\circ} \mathrm{C}\right)$. After complete thawing of the core (except $\sim 0.5 \mathrm{~cm}$ frozen layer neighboring the bottom limit of the core), freezing started at $-8^{\circ} \mathrm{C}$ and lasted 4 days. The freezing front direction was from both top and bottom of the peat cores towards the core center, similar to the spatio-temporal temperature pattern in peat soil found in the permafrost zone of the western Siberian Lowlands (Lim et al., 2021). The freeze/thaw experiment was performed the same way for all sections of the core. After complete freezing, the intact cores were removed from the chamber and sliced, still at negative temperature, by using a titanium saw into $5-\mathrm{cm}$ layers. Slices were placed into pre-cleaned polystyrene containers and allowed to thaw at $22^{\circ} \mathrm{C}$ in a laminar hood box for $24 \mathrm{~h}$. Note that the temperature (between 5 and $25^{\circ} \mathrm{C}$ ) per se has negligible impact on rate of DOC and element leaching from the peat (Paynadi-Dahedrey, 2020). As such, the short-term effect of bringing the core to room temperature for thawing, and thawing the frozen peat core layers prior filtration could not appreciably impact the degree of DOC and element leaching from the peat into the porewater.

Upon complete thaw, the peat was subjected to pore solution extraction following the procedure used in the field: via pressing through $100-\mu \mathrm{m}$ pre-cleaned Nylon net and subsequent centrifugation followed by filtration through a $0.45 \mu \mathrm{m}$ disposable Sartorius filter units. Note that we have not added any MilliQ water to the initial peat core, and the freeze-thaw cycle was conducted with original peat ice and interstitial solution. Because of bi-directional freezing, there was no any water loss at the bottom of the core sections.

\subsection{Analyses and statistical treatment}

Identical analyses have been performed on both the core sliced in the field and the laboratory after the freezing/thawing experiment. Prior sampling and analyses of bacteria, sterility of the part of the core collected for microbiological analysis was achieved using exclusively the peat material from the interior of the core (> $1 \mathrm{~cm}$ from the core liner) following conventional procedures (Morgalev et al., 2017; Coolen et al., 2011). For bacterial count, every $2 \mathrm{~cm}$ in depth, peat core samples were taken with a sharp sterile single-use knife and placed in sterile PVC double-zipped bags. Further subsampling was performed under sterile protected conditions in a laminar hood box (A100). The total number of microorganisms was determined in a Goryaev chamber (Morgalev et al., 2019). To determine the ratio of living and dead bacteria during freezing and repeated permafrost FTC, we modified the direct cell counting method by staining with the LIVE / DEAD ${ }^{\text {TM }}$ BacLight ${ }^{\text {TM }}$ Bacterial Viability Kit. This modification consisted of using a confocal microscope, for visually detecting the bacteria, counting their numbers and assessing the LIVE / DEAD ratio (Morgalev et al., 2019). 
For chemical analyses, the field cores were sliced in 10-cm layers and the experimental cores were sliced in $5 \mathrm{~cm}$ layers. A non-filtered subsample of porewater which was extracted after thawing of each peat layer was used to measure $\mathrm{pH}$ (uncertainty of $\pm 0.01 \mathrm{pH}$ units) and specific conductivity $\left( \pm 0.1 \mu \mathrm{S} . \mathrm{cm}^{-1}\right)$. The rest of the $15 \mathrm{~mL}$ was filtered through a $0.22 \mu \mathrm{m}$ filter (sterilizing filtration, Minisart@ syringe filter). In the filtrates, the DOC and DIC were analyzed by high-temperature catalytic oxidation using TOC-VCSN, Shimadzu ${ }^{\circledR}$ (uncertainty $\pm 2 \%, 0.1 \mathrm{mg} \mathrm{L}-1$ detection limit). The DIC was measured after sample acidification with $\mathrm{HCl}$ and $\mathrm{DOC}$ was analyzed in acidified samples after sparging it with C-free air for 3 min at $100 \mathrm{~mL} \mathrm{~min}^{-1}$ as non-purgable organic carbon (NPOC). The internationally certified water samples (MISSISSIPPI-03, Pérade-20) were used to check the validity and reproducibility of the analysis. The UVabsorbance of water samples was measured using a $10 \mathrm{~mm}$ quartz cuvette on a CARY-50 UV-vis spectrophotometer to assess the aromaticity of pore fluids via specific UV absorbance (SUVA 254 ). Major cations, Si, P and $\sim 40$ trace elements (TE) were measured with a quadrupole ICP-MS (Agilent $7500 \mathrm{ce}$ ) using In and Re as internal standards. The international geo-standard SLRS-5 (Riverine Water Reference Material for Trace Metals) was used to check validity and reproducibility of analyses. Because some elements are not certified in the SLRS-5, we used the values recommended by Heimburger et al. (2013) and Yeghicheyan et al. (2013) to assess the quality control on thirty-five uncertified elements (rare earth elements, B, Bi, Br, Cs, Ga, Ge, Hf, Li, Nb, P, Pd, Rb, Rh, S, Sc, Si, Sn, Th, Ti, TI, Y).

Principal component analysis (PCA) and Hierarchical Cluster Analysis (HCA) were used for the full set of sampled pore waters and permafrost ice. The PCA analysis (Varimax normalized, significant loading > 0.7) allowed to test the influence of core depth on the DOC and elemental concentrations. The HCA (Ward's method, 1-Pearson r) allowed for identification of elemental groups behaving similarly during FTE. All graphics and figures were created using MS Excel 2010, MS Visio Professional 2016 and GS Grapher 11 package. Statistical treatment was performed using STATISTICA-7 (http://www.statsoft.com).

\section{Results}

\subsection{Impact of freezing on concentration - depth profile for bacteria, major and trace elements.}

After freeze/thaw experiment (FTE) of 3 sections of the peat core, the pattern of total bacterial count demonstrated new concentration peaks at 40,60 and $80 \mathrm{~cm}$. This corresponded to three subsections of the core $(15-50,50-70$ and $70-95 \mathrm{~cm})$ studied in this work. There was also a downward shift of existing peaks (at 31 and $60 \mathrm{~cm}$ ) (Fig. 1A). The overall amount of cells also increased after FTE, by a factor of 1.3 to 3 , depending on the depth of the core. About $20 \%$ of all cells were initially dead; this proportion remained fairly constant over the full depth of the peat core and did not appreciably change after FTE. Note that experimental reproducibility of bacterial count was assessed on three field cores (Fig. 1A). The reproducibility of TBC ranged from 10 to $30 \%$ in the peat water and ice and demonstrated significant difference in TBC profile before and after freeze-thaw experiment. 
Experiments on three artificial 50 -cm long homogenized peat cores, saturated each column with water in the amount comparable to that in the environment, demonstrated reasonable agreement in $\mathrm{pH}$, Specific Conductivity and $U_{254} \mathrm{~nm}$ absorbance of peat porewater and ice (Fig. S1). In particular, the UV absorbance (which is a surrogate for DOC concentration) demonstrated a local minimum in the middle of the core, at $25 \mathrm{~cm}$ depth which is reproducible among three replicates.

The $\mathrm{pH}$ of pore waters and ice from 3 sections of natural peat core varied between 3.5 and 3.8 after FTE. The FTE sizably changed the $\mathrm{pH}$ of the fluid phase via shifting it by 0.1 to 0.5 units towards less acidic environment compared to the original peat core; this effect was mostly pronounced in the active (unfrozen) layer (Fig. S2 A). The Specific Conductivity did not differ before and after FTE, and ranged from $100-150 \mu \mathrm{S} \mathrm{cm}^{-1}$ in the first $60 \mathrm{~cm}$ to $200-250 \mu \mathrm{S} \mathrm{cm}^{-1}$ at $70-95 \mathrm{~cm}$ depth (Fig. S2 B). After FTE, the DOC concentration in peat pore water increased over the majority of the core; in each section of the core, peaks (at 40, 55 and $75 \mathrm{~cm}$ depth) were also noted (Fig. 1B). The SUVA 254 remained unchanged below 40 $\mathrm{cm}$ depth but strongly decreased in the layer between 20 and $40 \mathrm{~cm}$ (Fig. S2 C).

The macronutrients in pore water and ice of three sections of natural peat core exhibited strong local $(\mathrm{P}$, $\mathrm{Ca}$ at $75 \mathrm{~cm}$ ) or global (K) enrichment after FTE. In contrast, Si pattern was almost unchanged after freezing although small peaks of Si concentration appeared in each of the three sections (Fig. 1C, D and S2 D, E). Major metal components of peat pore water colloids - Fe and Al - exhibited local peaks at 70-75 cm depth (Fig. 1E, F). Other trace elements-metal micronutrients, toxicants or geochemical tracersexhibited one of the following main patterns: $i$ ) a single peak at $45 \mathrm{~cm}(\mathrm{~B}, \mathrm{Cr}, \mathrm{Ni}, \mathrm{Y}, \mathrm{REE}, \mathrm{Nb}, \mathrm{Ti}, \mathrm{Zr}, \mathrm{Hf}, \mathrm{Th}$, $\mathrm{U})$ or $75 \mathrm{~cm}(\mathrm{Co}, \mathrm{Sr}, \mathrm{Zn})$ depth; ii) multiple peaks over the full length of the column ( $\mathrm{Cu}, \mathrm{Cd}, \mathrm{Pb}, \mathrm{Sb}, \mathrm{Mo}$, $\mathrm{Sn}$ ); iii) a lack of clear vertical pattern but displaying similarity ( $\mathrm{Li}, \mathrm{Na}, \mathrm{Mg}, \mathrm{Ba}, \mathrm{V}, \mathrm{Mn}, \mathrm{Ge}, \mathrm{As}, \mathrm{Cs}$ ) or global enrichment $(\mathrm{Rb}, \mathrm{Sb}, \mathrm{Tl})$ comparable to the one before FTE. The illustrations of representative elements are provided in Fig. 1G-I. The panels in this figure show typical micronutrients strongly linked to organic matter and exhibiting one (Ni, La) or multiple ( $\mathrm{Zn}$ ) concentration maxima. Examples of other micronutrients ( $\mathrm{Mn}, \mathrm{Co}, \mathrm{Mo}$ ), toxicants ( $\mathrm{Cd}, \mathrm{Sb}, \mathrm{Pb}$ ) and geochemical tracers ( $\mathrm{Sr}, \mathrm{Ti}, \mathrm{Zr}, \mathrm{Nb}, \mathrm{U}$ ) are shown in Fig. S2 G-I and S3 A-I of the Supplement. Overall, the appearance and the position of concentration maxima were different among different elements. However, in all cases the new peaks were located within the borders of each of the three experimental subsections.

The relative enrichment of elements in the fluid phase after FTE was quantified as the ratio of depthweighed elemental concentration after laboratory FTE to that in the original peat core (interstitial pore water and dispersed ice), integrated over the depth of the peat core subjected to freezing and thawing (20 to $90 \mathrm{~cm}$ from the surface, Fig. 2A). For comparison, we also calculated the ratio of median concentrations in the permafrost layer ( $40-90 \mathrm{~cm}$ depth, below the ALT) of the experimental (post F/T) and the initial natural core (Fig. 2B). Furthermore, the ratio of peaks of element concentrations (at the depth, specific for each element) between three experimental sections and field peat core was also calculated (Fig. 2C). 
It can be seen from a histogram of the ratios of elemental concentrations after FTE compared to those prior freezing that bacterial number, $\mathrm{DOC}, \mathrm{P}$ and a number of major elements $(\mathrm{Ca}, \mathrm{K}, \mathrm{Mg})$, micronutrients (B, Mn, Rb, Cu, Ni, Co, Ba, Zn), toxicants (Cd, Sb, Sn) and geochemical tracers (Ga, Ge, Nb, REE, Th, W) exhibited sizable (a factor of 2 to 5 ) enrichment in peat porewater after FTE. Other elements demonstrated an enrichment factor of 2 to 1 , which was often within the uncertainties (standard deviation of the average value from different layers). Such relatively low value marked an excess of a given element in one single layer rather than a global enrichment.

\subsection{Multi-parametric treatment (PCA and HCA).}

To infer the link of elements to possible factors operating during FTE, a multi-parametric treatment of the data was attempted including Principal Component Analysis (PCA) of the full depth of the peat core. Two main factors were distinguished that may explain $65.7 \%$ of the variability (Fig. S4 A). The first factor (42.4\%) was primarily linked to depth of the layer and DOC concentration acting on specific conductivity and labile elements ( $\mathrm{Li}, \mathrm{Mg}, \mathrm{Ca}, \mathrm{P}, \mathrm{Si}, \mathrm{K}, \mathrm{V}, \mathrm{Rb}, \mathrm{Sr}, \mathrm{As}, \mathrm{Mo}, \mathrm{Cs}$ ), Fe, Al, and divalent nutrients (Mn, Co) concentrations. The second factor $(22.4 \%)$ was primarily linked to concentration of bacteria, $\mathrm{SUVA}_{254}$ and included a number of low mobility insoluble elements ( $T i, Y, R E E, N b, Z r, T h, U)$.

The HCA treatment of peat porewater and ice chemical composition before and after FTE generally confirmed two clusters of peat pore water components (Fig. S4 B). The 1st group included core depth, DOC, S.C., most soluble labile elements ( $\mathrm{Mg}, \mathrm{K}, \mathrm{Si}, \mathrm{Rb}, \mathrm{Cs}$, alkali and alkaline-earth metals and some divalent transition metals). The 2nd group included bacterial number, $\mathrm{Ti}, \mathrm{Cu}, \mathrm{Ni}, \mathrm{Y}, \mathrm{REE}, \mathrm{U}, \mathrm{Th}$ ).

\section{Discussion}

\subsection{Mechanisms for bacterial cell and element enrichment in peat porewater after the freeze-thaw experiment.}

The physico-chemical processes capable of shaping the bacteria and solutes ( $<0.45 \mu \mathrm{m}$ fraction) depth profile in a peat core subjected to the freezing and thawing are illustrated in Fig. 3 and these are: $i$ ) element and DOC leaching from peat matrix, ii) peat grain disintegration and transformation of small solid particles into large-size aquatic colloids, iii) opening of non-connected pores and mobilization of their interior to the bulk fluid phase, iv) vertical movement of solutes and colloids via upward or downward freezing front migration leading to exclusion of most solutes from forming ice and finally $v$ ) occlusion (capture) of some ions, molecules or colloids within the ice structure.

The freezing of the peat core led to shifting of the initial peak of bacteria at $31 \mathrm{~cm}$ and the appearance of new pronounced maxima at 53 and $84 \mathrm{~cm}$. The most likely explanation for this is bacterial exclusion from ice formation during two freezing front migrations resulting in cell concentration at the freezing fronts meeting point, as has been shown for algal suspensions (Morgalev et al., 2019). In addition, mobilization of cells from previously non-connected peat pores cannot be excluded. Indeed, Rezanezhad et al. (2016) demonstrated existence of three pore classes in the peat: 1) open and connected pores 
accounting for approximately $35 \%$ of total porosity, 2) closed or partially closed pores accounting for about $20 \%$ of total porosity, and dead-end or isolated pores that roughly account for the remaining $45 \%$ of total porosity in poorly degraded fen peat. These immobile regions, unaffected by advective flow, are suggested to be primary sites for microbial biogeochemical processes in peat (McCarter et al., 2020). Further, peat pore dilation during pore water freezing may result in increased hydraulic conductivity (Kennedy and Price, 2005). Taking into account these observations, we hypothesize that a sizable increase in the concentration of peat pore water $\mathrm{DOC}$ after freezing-thawing over the full peat core length (Fig. 1B) can be linked to mobilization of DOC from pockets of water in these confined pores.

Another possible mechanism responsible for DOC concentration increase in the fluid phase after FTE is peat grain disintegration leading to an increase in the reactive surface area and thereby enhanced release of DOC from peat constituents. Simultaneously, generation of new colloidal DOC and metal from particles can occur. Note that, for mineral soils, physical disruption of aggregates during freezing events is known to involve expansion of pore structures via the formation of ice crystals (Six et al., 2004) and micro-scale fractures, as it was demonstrated for limestone (De Kock et al., 2015). Although peat is less likely to present sizable aggregation compared to mineral soils, some grains, especially those having internal (non-connected) pores (i.e., Rezanezhad et al., 2016) still may disintegrate and expose their inner surfaces to the external milieu. Such an enhanced mobilization of elements from the peat to the fluid phase is likely responsible for the overall enrichment of the peat core fluid phase in DOC, K, Cd, Co, Sr, Sb and the appearance of concentration peaks for some nutrients, major and trace elements. The most pronounced effects were observed for $\mathrm{P}$ and trivalent ( $\mathrm{Al}, \mathrm{Fe}, \mathrm{Y}, \mathrm{REE})$ and tetravalent ( $\mathrm{Ti}, \mathrm{Zr}, \mathrm{Hf}, \mathrm{Th}$ ) cations. Most likely, insoluble and low mobile $\mathrm{TE}^{3+}$ and $\mathrm{TE}^{4+}$ are strongly bound to organic matter and follow the DOC pattern in the upper part of the peat column. As a result, these cations show a maximum at the layer of DOC enrichment where the concentration of organic matter due to freezing front migration presumably occurs.

Note that one of the factors responsible for $\mathrm{C}$ and nutrient enrichment in soil after FTE is microbial cell Iysis (Sharma et al., 2006; Schimel and Clein, 1996; Kumar et al., 2013). In the present work, the bacterial number generally increased, not decreased, after FTE of the peat core and the proportion of live cells remained constant (around $80 \%$ ). Furthermore, given that, after FTE, the peat porewater was enriched in both nutrients from cell interior ( $\mathrm{P}, \mathrm{K}, \mathrm{Ca}$ ) and biologically indifferent or toxic elements $(\mathrm{Cu}, \mathrm{Cd}, \mathrm{Sn}, \mathrm{Ge}, \mathrm{Ni}$, Th, La; see Fig. 2), cell lysis could have only a negligible influence on peat porewater enrichment in this study.

Among other possible factors affecting DOC and metal leaching from peat to the aqueous fluid could be the solution $\mathrm{pH}$. The F/T experiment sizably changed the $\mathrm{pH}$ of the fluid phase via shifting it by 0.1 to 0.5 units towards less acidic environment. It is known that higher $\mathrm{pH}$ can promote phenol oxidase activity which is capable of increasing DOC (Kang et al., 2018).

However, the time scale of field and laboratory experiments of Kang et al (2018) is much longer than that in the present study, so this effect can be of secondary importance for enhancing pore water DOC 
concentration. As for the $\mathrm{pH}$ impact on peat leachability, our recent experiments (Payandi-Rolland et al., 2020) did not demonstrate any link between the $\mathrm{pH}$ (range from 4.1 to 4.5) of leachate and the rate of DOC removal from the peat to the aqueous solution. Nevertheless, further experiments on the $\mathrm{pH}$ impact on release of ions and organo-metal complexes and colloids from the peat are needed to address this possibility.

\subsection{Dominant role of freezing front migration in determining the vertical pattern of DOC, bacteria and trace elements in peat pore waters and ice}

The freeze-thaw cycles are known to accumulate some ions at the base of the active layer and uppermost permafrost because solutes are excluded downwards during the fall freeze-up (Kokelj and Burn, 2005; French and Shur, 2010). As a result, the solute accumulation due to freeze-out enrichment could lead to concentrations being ten to hundreds times greater in the upper part of the permafrost than in the active layer (Kokelj and Burn, 2005; Lamhonwah et al., 2016, 2017). These observations are consistent with recent results of chemical composition of the peat ice in native cores from permafrost peatland (Lim et al., 2021). During freezing of aqueous solutions from surface waters of Arctic peatlands similar (but less concentrated in DOC and metals) to peat porewater, a progressive freezing of water from reactor edges to the center led to relative accumulation of DOM in the remaining liquid (Pokrovsky et al., 2018; PayandiRolland et al., 2021).

Consistent with these previous observations and recent experimental results, we interpret the peaks of $\mathrm{DOC}, \mathrm{Ca}, \mathrm{Cu}, \mathrm{Cd}, \mathrm{Pb}$ and trivalent and tetravalent trace elements at different depths observed in this study as due to meeting of freezing fronts for each section of the peat core after freeze/thaw experiment. These divalent metals and insoluble $\mathrm{TE}^{3+}, \mathrm{TE}^{4+}$ trace elements are known to be strongly associated with dissolved organic matter (DOM) in peat porewater (i.e., Raudina et al., 2021). During freezing front propagation, large size organic-Fe-Al colloids $(30 \mathrm{kDa}-0.45 \mu \mathrm{m})$ are subjected to preferential exclusion relative to truly dissolved (inorganic) solutes from the ice. As a result, they form precipitates once the threshold of their "solubility" is attained. This most likely happens in parts of the core where two freezing fronts meet. As such, the local maxima in DOC and related metal concentrations at (40, 55-60 and 75-80 $\mathrm{cm}$ depths for likely correspond to meeting points of freezing fronts in three different sections of the peat core $(15-50,50-70$, and 70-95 cm) subjected to bi-directional freezing (Fig. 3).

From experiments on aqueous systems, it is known that the impurities (soluble salts as well as suspended materials) are appreciably forced out by a dynamic freezing front (Shafique et al., 2012 and references therein). Furthermore, it was shown that a high concentration of DOM and low freezing temperatures diminish the proportion of DOM incorporated in the ice phase (Elliott and Henry, 2009; Hentschel et al., 2008; Xue et al., 2015), whereas some parts of ionic solutes and even organic colloids could be occluded (incorporated) in the ice in the form of liquid pockets as is known for sea ice formation (Petrich and Eicken, 2010). The mechanisms of freeze-induced coagulation of organic and organomineral colloids in peat are poorly understood (McCarter et al., 2020) but may include flocculation due to an increase in concentration of DOC and DOM-metal complexes and colloids. This flocculation may 
occur locally at the freezing front or in stagnant pockets of the remaining fluid. The exact chemical nature and stoichiometry of these particulate coagulates containing $\mathrm{C}_{\text {org }}, \mathrm{Fe}, \mathrm{Al}$ and various trace elements are not known. Organo-mineral composites formed by Fe (hydr)oxides in association with organic matter (OM) are important vectors of trace metal and bioessential element transport and retention in soils and groundwaters (McCarthy and Zachara, 1989; Murphy and Zachara, 1995; Otero Farina et al., 2018). During freezing of aqueous organic-rich solutions, organic matter coagulates in the ice due to changes in particle density and diameter (Fellman et al., 2008; Giesy and Briese, 1978). This coagulation is frequently accompanied by formation of organo-metal (Fe, Al) hydroxide aggregates (Pokrovsky et al., 2018; Payandi-Rolland et al., 2021). The latter study demonstrated a reversibility of OM- metal particle precipitation during repetitive freezing and thawing of $<0.45 \mu \mathrm{m}$-filtered peat leachates and natural waters from peatland depressions. We therefore hypothesize that freezing-induced concentration and precipitation of organo-mineral $(\mathrm{Fe}, \mathrm{Al})$ aggregates with trace elements in peat porewaters is a reversible process. As a result, after peat ice thawing, the fluid phase recovers most of these solutes at the site of their deposition (Fig. 3). It has to be noted that the solutes and bacteria behaved differently during F/T experiment: the post F/T peaks of DOC and related metals (40,55 and $75 \mathrm{~cm}$ depth) were not exactly the same that those of the TBC $(31,53$ and $84 \mathrm{~cm})$, while they were both related to the freezing front meeting point. Presumably, the exclusion of colloids and particles at the freezing front migration occurs differently due to their different diffusion rate and degree of occlusion in the ice pockets.

Interestingly, a strong local maximum after FTE was observed for $\mathrm{P}$ and $\mathrm{Al}$ at $75 \mathrm{~cm}$ depth. This could be linked to formation of Al phosphate with its subsequent OM-promoted dissolution upon thawing. Certain divalent metals ( $\mathrm{Ca}, \mathrm{Sr}, \mathrm{Co}, \mathrm{Zn}, \mathrm{Pb}$ ) also demonstrated a concentration peak at this depth, suggesting concomitant retention/release via co-precipitation/dissolution of Al phosphates. Note that phosphorus binding to soil organic matter via ternary complexes with calcium is well known (Audette et al., 2020). Similar yet unknown complexes may govern coprecipitation of $\mathrm{Sr}, \mathrm{Co}, \mathrm{Zn}$ and $\mathrm{Pb}$ with $\mathrm{Ca}$ phosphates in the presence of extremely high concentrations of DOC $\left(\sim 1000 \mathrm{mg} \mathrm{L}^{-1}\right)$ in porewaters of the deep parts of the peat column.

The PCA treatment of obtained results demonstrated that two factors are capable of explaining $66 \%$ of elemental variability across the peat core after FTE: 1) the depth and DOM acting on mobile soluble elements such as $\mathrm{Li}, \mathrm{Mg}, \mathrm{Si}, \mathrm{P}, \mathrm{K}, \mathrm{V}, \mathrm{As}, \mathrm{Rb}, \mathrm{Sr}, \mathrm{Mo}, \mathrm{Cs}$ but also metal cations present in organic complexes (Al, $\mathrm{Mn}, \mathrm{Fe}, \mathrm{Co}, \mathrm{V}$ ) and 2) the total bacterial number and SUVA were associated with low mobile $\mathrm{Ti}, \mathrm{Y}, \mathrm{Nb}$, REEs, $\mathrm{Th}, \mathrm{Nb}, \mathrm{Zr}$ and $\mathrm{U}$. It is possible the 1st factor reflects the gradual change of elemental composition over the peat core as trace elements were subjected to reversible precipitation and dissolution following achievement of specific threshold concentrations. The 2 nd factor likely reflects the migration of large size particles such as bacteria or high molecular weight organo-mineral colloids. Both were excluded from the ice, concentrated during freezing front migration and precipitated in specific sites of the peat core, typically where the two freezing fronts meet.

4.3. Importance of peat soil freeze/thaw in transformation of chemical composition and microbial population in natural settings

Page $11 / 21$ 
In non-permafrost environments, FTC of various soils from marshes and wet grasslands yield strong DOC production (100 to $300 \mathrm{mg} \mathrm{L}^{-1}$ ) compared to samples not subjected to these cycles (Yu et al., 2011). Generally, an increase in $\mathrm{C}$ and nutrients in soils subjected to freezing is believed to be a consequence of microbial cells lysis, physical disruption of soils aggregates, and root turnover (Bochove et al., 2000; DeLuca et al., 1992; Ivarson and Sowden, 1970; Tierney et al., 2001). However, the majority of studies from the non-permafrost zones dealt with either natural manipulation (change of freezing/thawing regime) or with laboratory experiments adding distilled water. Here, we studied for the first time, intact peat cores which allowed the role of freezing on transformation of original peat pore water to be revealed.

The first important observation of this study is a sizable increase in the concentration of numerous components over the full depth of the core or in selected zones without decreasing in elemental concentrations along other parts of the core (Fig. 2). Therefore, freezing does not lead to the irreversible coagulation of colloids and transformation of $<0.45 \mu \mathrm{m}$ fraction DOC and elements into particulate (> $0.45 \mu \mathrm{m})$ forms. A likely reason for this feature is the high stability of colloids in acidic $(\mathrm{pH}<4)$ peat porewaters waters. This is consistent with results of experiments of repetitive freezing-thawing on acidic bog waters (Payandi-Rolland et al., 2021). In contrast, in neutral $(\mathrm{pH}>6)$ fen or river waters, there is a sizable freeze-induced coagulation of colloids and irreversible removal of dissolved $(<0.45 \mu \mathrm{m})$ forms of elements (Pokrovsky et al., 2018). In this regard, experiments on circum-neutral peat from fen environments are important as they can reveal strong coagulation and immobilization of DOC and related elements after freezing.

The consequence of obtained results is that, with progressive increase in frequency of freeze-thaw processes in the permafrost peatlands and an increase in the ALT during permafrost thaw, there will be no retention of soil pore water organic matter and related major and trace elements due to possible freezinginduced coagulation. Even when this coagulation occurs, it is quite reversible and capable of maintaining the concentration of solutes in peat pores. With increase of ALT, previously frozen peat porewater (in the form of dispersed ice) becomes labile and constitutes an essential source of available organic matter and cations, comparable or greatly exceeding the current lateral riverine export of DOC and some nutrients (P, Zn) from the watershed (Lim et al., 2021). Results from this study demonstrate that, in addition to this "physical" mobilization of peat ice solutes, seasonal freezing of recently (previous summer) thawed peat cores may produce a local maxima (by a factor of 2 to 5 ) of pore waters in DOC, nutrients $(\mathrm{P}, \mathrm{K}, \mathrm{Ca}, \mathrm{Ni}, \mathrm{Mn})$ and some trace elements as evidenced from three independent sections of core freezing/thawing in this study. Two most likely mechanisms of this enrichment are leaching of peat constituents and opening of previously isolated pores.

Another implementation of obtained results is that the appearance of one or several concentration peaks of bacteria or elements in peat ice cores after even a single freeze/thaw event does not allow direct use of peat fluid chemical and microbiological composition for paleo-reconstructions. For example, in the case of progressive increase in the ALT, a single maximum (concentration peak in the peat core) will decrease downwards. Contrastingly, in case of progressive cooling and moving of ALT boundary upwards-when the thawing zone does not reach the existing peak-new concentration maxima will be formed in the 
upper parts of peat cores. As a result, multiple peaks of element concentrations in the dispersed ice of the peat core may indicate multiple paleo cooling/thawing events. However, exact position of these maxima may vary depending on local peat structure and water availability which requires thorough calibration using multiple peat cores of the region, accompanied by ${ }^{14} \mathrm{C}$ dating of DOM in both solid phase and ice below the active layer.

\section{Conclusions}

Experimental modelling of bi-directional freezing/thawing of peat from discontinuous permafrost peatlands in western Siberia demonstrated a measurable impact on bacterial number, DOC, nutrient and metal concentration in peat porewater and dispersed ice. After a single F/T experiment, the fluid phase of the peat core was substantially (by a factor of 2 to 5 ) enriched in bacterial cells, DOC, macro- and micronutrients $(\mathrm{P}, \mathrm{K}, \mathrm{Ca}, \mathrm{Rb})$ and numerous indifferent or toxic elements. The experiment revealed a complexity of processes responsible for freeze-induced enrichment of peat porewaters such as enhanced leaching of peat constituents to the fluid phase, disintegration of peat particles into large size organo-mineral colloids, the change of pore-scale structure related to the opening of previously closed pores leading to increasing connectivity. The impact of increasing the solutes and colloids concentration on phase change temperature can be also invoked although not addressed explicitly in this work. Furthermore, freezing front migration translocated pre-existing concentration maxima in bacteria, DOC and inorganic solutes in peat porewaters via downward shifting of element peaks. Mechanisms for element translocation during freezing may include reversible precipitation / dissolution of organo-mineral composites at the layer where the two freezing fronts meet and occlusion of ionic and colloidal forms of elements into ice structure and solution pockets.

Results of this study provided two main consequences for natural peatlands that are subjected to permafrost thaw and active layer thickness increase: 1 ) there exists possibility for sizable surface water enrichment in DOC, nutrients and metals due to seasonal thawing-freezing of previously permanently frozen peat below the active layer, and 2) the concentration peaks of peat ice solutes observed in natural cores can be reproduced via bi-directional freezing. However, strong translocation of solute peaks after freeze-thaw events may prevent using the peat chemical archives for paleo-reconstructions.

\section{Declarations}

\section{Acknowledgements}

The study was carried out using the research equipment of the Unique Research Installation "System of experimental bases located along the latitudinal gradient" TSU.

\section{Ethical Approval}

Not applicable 


\section{Consent to Participate}

Not applicable

\section{Consent to Publish}

Not applicable

\section{Authors Contributions}

Sergey Y. Morgalev: experiments, writing; Artem G. Lim: Writing, Analyses, Yuri N. Morgalev: Conceptualization; Daria Kuzmina: field sampling; Tamara G. Morgaleva: experiments, bacterial analysis; Liudmila S. Shirokova: chemical analyses; Rinat M. Manasypov: Analyses; Laurent Orgogozo: Interpretation; Sergey V. Loiko: Conceptualization; Oleg S. Pokrovsky: Writing, Supervision

\section{Funding}

Supports from the Ministry of Science and Higher Education of the Russian Federation, project No. 07212020-0019 (laboratory research), RSF No 18-77-10045 (field research), RFBR No 19-55-15002, 20-0500729 projects, the ANR-19-CE46-0003 HiPerBorea, and the VULCAR-FATE project of the Belmont Forum are acknowledged.

\section{Competing Interests}

The authors declare no competing interests.

\section{Availability of data and materials}

All obtained data are presented in tables and figures of the manuscript and Supplementary Materials.

\section{References}

1. Audette Y, Smith DS, Parsons CT, Chen W, Rezanezhad F (2020) Phosphorus binding to soil organic matter via ternary complexes with calcium. Chemosphere 260:127624. http://dx.doi.org/10.1016/j.chemosphere.2020.127624

2. Bochove E van, Prévost D, Pelletier F (2000) Effects of freeze-thaw and soil structure on nitrous oxide produced in a clay soil. Soil Sci Soc Am J 64:1638-1643. https://doi.org/10.2136/sssaj2000.6451638x

3. Chen J, Xue S, Lin Y, Wang C, Wang Q, Han Q (2016) Effect of freezing-thawing on dissolved organic matter in water. Desalination Water Treat 57:17230-17240. https://doi.org/10.1080/19443994.2015.1085913

4. Chung H Y, Jung J, Lee D H, Kim S, Lee M K, Lee J I, Yoo K - C, Lee Y I, Kim K (2020) Chemical weathering of granite in ice and its implication for weathering in polar regions. Minerals 
10:185. https://doi: 10.3390/min10020185

5. Coolen M J L, van de Giessen J, Zhu E Y, Wuchter C (2011) Bioavailability of soil organic matter and microbial community dynamics upon permafrost thaw. Environ Microbiol 13(8):2299-2314. https://doi.org/10.1111/j.1462-2920.2011.02489.x

6. De Kock T, Boone M A, De Schryver T, Van Stappen J, Derluyn H, Masschaele B, Schutter G D, Cnudde V (2015) A pore-scale study of fracture dynamics in rock using Xray micro-CT under ambient freeze-thaw cycling. Environ Sci Technology 49 (5):28672874. https://doi.org/10.1021/es505738d

7. DeLuca T H, Keeney D R, McCarty G W (1992) Effect of freeze-thaw events on mineralization of soil nitrogen. Biol Fertil Soils 14:116-120. https://doi.org/10.1007/BF00336260

8. Elliott A C, Henry H A L (2009) Freeze-thaw cycle amplitude and freezing rate effects on extractable nitrogen in a temperate old field soil. Biol Fertil Soils 45:469-476. https://doi.org/10.1007/s00374009-0356-0

9. Fellman J B, D’Amore D V, Hood E (2008) An evaluation of freezing as a preservation technique for analyzing dissolved organic C, N and P in surface water samples. Sci Total Environ 392:305-312. https://doi.org/10.1016/j.scitotenv.2007.11.027

10. Fitzhugh R D, Driscoll C T, Groffman P M, Tierney G L, Fahey T J, Hardy J P (2003) Soil freezing and the acid-base chemistry of soil solutions in a northern hardwood forest. Soil Sci Soc Am J 67:18971908

11. French H, Shur Y (2010) The principles of cryostratigraphy. Earth-Science Reviews 101:190-206. https://doi.org/10.1016/j.earscirev.2010.04.002

12. Giesy J P, Briese L A (1978) Particulate formation due to freezing humic waters. Water Resour Res 14:542-544. https://doi.org/10.1029/WR014i003p00542

13. Hayashi M (2013) The cold vadose zone: Hydrological and ecological significance of frozen-soil processes. Vadoze Zone J 12(4):1-8. https://doi.org/10.2136/vzj2013.03.0064

14. Heimburger A, Tharaud M, Monna F, Losno R, Desboeufs K, Nguyen E (2013) SLRS-5 elemental concentrations deduced from SLRS-5/SLRS-4 ratios of thirty-three uncertified elements. Geostandards Geoanalyt Research 37 (1):77-85. 10.1111/j.1751-908X.2012.00185.x

15. Henry H A L (2008) Climate change and soil freezing dynamics: historical trends and projected changes. Clim Change 87:421-434. https://doi.org/10.1007/s10584-007-9322-8

16. Hentschel K, Borken W, Matzner E (2008) Repeated freeze-thaw events affect leaching losses of nitrogen and dissolved organic matter in a forest soil. J Plant Nutr Soil Sci 171:699-706. https://doi.org/10.1002/jpln.200700154

17. Ivarson K C, Sowden F J (1970) Effect of frost action and storage of soil at freezing temperatures on the free amino acids, free sugars and respiratory activity of soil. Can J Soil Sci 50:191-198. https://doi.org/10.4141/cjss70-027

18. Jiang N, Juan Y, Tian L, Chen X, Sun W, Chen L (2018) Modification of the composition of dissolved nitrogen forms, nitrogen transformation processes, and diversity of bacterial communities by freeze- 
thaw events in temperate soils. Pedobiologia 71:41-49, https://doi.org/10.1016/j.pedobi.2018.08.004

19. Kang H, Kwon M J, Kim S, Lee J, Jones T G, Johncock A C, Haraguchi A, Freeman C (2018) Biologically driven $\mathrm{DOC}$ release from peatlands during recovery from acidification. Nature Communications 9. https://doi.org/10.1038/s41467-018-06259-1

20. Kennedy G, Price J (2005) A conceptual model of volume-change controls on the hydrology of cutover peats. J Hydrol 302:13-27. https://doi.org/10.1016/j.jhydrol.2004.06.024

21. Kim E-A, Lee H K., Choi J H (2017) Effects of a controlled freeze-thaw event on dissolved and colloidal soil organic matter. Environ Sci Pollut Res 24:1338-1346. https://doi.org/10.1007/s11356016-7552-x

22. Kim E-A, Choi J H (2018) Changes in the mineral element compositions of soil colloidal matter caused by a controlled freeze-thaw event. Geoderma 318:160-166. https://doi.org/10.1016/j.geoderma.2017.10.056

23. Kokelj S V, Burn C R (2005) Geochemistry of the active layer and near-surface permafrost, Mackenzie delta region, Northwest Territories, Canada. Canadian Journal of Earth Sciences 42:37-48

24. Kumar N, Grogan P, Chu H, Christiansen C T, Walker V K (2013) The effect of freeze-thaw conditions on Arctic soil bacterial communities. Biology 2:356-377. https://doi.org/10.3390/biology2010356

25. Lamhonwah D, Lafrenière M J, Lamoureux S F, Wolfe B B (2017) Evaluating the hydrological and hydrochemical responses of a High Arctic catchment during an exceptionally warm summer. Hydrological Processes 31:2296-2313. https://doi.org/10.1002/hyp.11191

26. Lamhonwah D, Lafrenière M J, Lamoureux S F, Wolfe B B (2016) Multi-year impacts of permafrost disturbance and thermal perturbation on High Arctic stream chemistry. Arctic Science 3:254-276. https://doi.org/10.1139/as-2016-0024.

27. Larsen K S, Jonasson S, Michelsen A (2002) Repeated freeze-thaw cycles and their effects on biological processes in two arctic ecosystem types. Appl Soil Ecol 21:187-195. https://doi.org/10.1016/S0929-1393(02)00093-8

28. Lim A G, Loiko S V, Kuzmina D, Krickov I V, Shirokova L S, Kulizhsky S P, Vorobyev S N, Pokrovsky O S (2021) Dispersed ground ice of permafrost peatlands: a non-accounted for source of $C$, nutrients and metals. Chemosphere 226:128953. https://doi.org/10.1016/j.chemosphere.2020.128953

29. Loiko S, Raudina T, Lim A, Kuzmina D, Kulizhskiy S, Pokrovsky O (2019) Microtopography controls of carbon and related elements distribution in the west siberian frozen bogs. Geosciences (Switzerland) 9 (7):291, https://doi.org/10.3390/geosciences 9070291

30. Ma Q, Jin H, Yu C, Bense V.F (2019) Dissolved organic carbon in permafrost regions: A review. Sci China Earth Sci 62:349-364. https://doi.org/10.1007/s11430-018-9309-6

31. McCarter C P R, Rezanezhad F, Quinton, W L, Gharedaghloo B, Lennartz B, Price J, Connon R, Van Cappellen P (2020) Pore-scale controls on hydrological and geochemical processes in peat: Implications on interacting processes. Earth-Sci Rev 207:103227. https://doi.org/10.1016/j.earscirev.2020.103227 
32. McCarthy J F, Zachara J M (1989) Subsurface transport of contaminants. Environ Sci Technol 23:496-502. https://doi.org/10.1021/es00063a001

33. Morgalev Y N, Lushchaeva I V, Morgaleva T G, Kolesnichenko L G, Loiko S V, Krickov I V, Lim A, Raudina T V, Volkova I I, Shirokova L S, Morgalev S Y, Vorobyev S N, Kirpotin S N, Pokrovsky O S (2017) Bacteria primarily metabolize at the active layer/permafrost border in the peat core from a permafrost region in western Siberia. Polar Biol 40:1645-1659. https://doi.org/10.1007/s00300-0172088-1

34. Morgalev S Y, Morgaleva T G, Morgalev YN, Loiko SV, Manasypov R M, Lim A G, Pokrovsky O S (2019) Experimental modeling of the bacterial community translocation during freezing and thawing of peat permafrost soils of Western Siberia. IOP Conference Series: Earth and Environmental Science 400 (1):012017. https://doi.org/ 10.1088/1755-1315/400/1/012017

35. Müller S, Vähätalo A V, Stedmon C A, Granskog M A, Norman L, Aslam S N, Underwood G J C, Dieckmann G S, Thomas D N (2013) Selective incorporation of dissolved organic matter (DOM) during sea ice formation. Marine Chem 155:148-

157. https://doi.org/10.1016/j.marchem.2013.06.008

36. Murphy E M, Zachara J M (1995) The role of sorbed humic substances on the distribution of organic and inorganic contaminants in groundwater. Geoderma 67:103-124. https://doi.org/10.1016/00167061(94)00055-F

37. Nagare R M, Schincariol R A, Quinton WL, Hayashi M (2012a) Effects of freezing on

38. soil temperature, freezing front propagation and moisture redistribution in peat: laboratory investigations. Hydrol Earth Syst Sci 16(2):501-515. https://doi.org/10.5194/hess-16-501-2012

39. Nagare R M, Schincariol R A, Quinton W L, Hayashi M (2012b) Moving the field into the lab: Simulation of water and heat transport in Subarctic Peat. Permafrost Periglacial Proc 23(3):237-243. https://doi.org/10.1002/ppp.1746

40. Otero Farina A, Peacock C L, Fiol S, Antelo J, Carvin B (2018) A universal adsorption behaviour for Cu uptake by iron (hydr) oxide organo-mineral composites. Chem Geol 479:22-35. https://doi.org/10.1016/j.chemgeo.2017.12.022

41. Payandi-Rolland D, Shirokova L S, Nakhle P, Tesfa M, Abdou A, Causserand C, Lartiges B, Rols J-L, Guérin F, Bénézeth P, Pokrovsky OS (2020) Aerobic release and biodegradation of dissolved organic matter from frozen peat: Effects of temperature and heterotrophic bacteria. Chem Geol 536:119448. https://doi.org/10.1016/j.chemgeo.2019.119448

42. Payandi-Rolland D, Shirokova L S, Labonne F, Bénézeth P, Pokrovsky O S (2021) Low impact of freeze-thaw cycles on organic carbon and metals in waters of permafrost peatlands. Chemosphere 279:130510, https://doi.org/10.1016/j.chemosphere.2021.130510.

43. Petrich C, Eicken H (2010) Growth, Structure and Properties of Sea Ice. In: Thomas D N, Dieckmann G S (ed) Sea Ice. Publisher: John Wiley \& Sons, pp 23-77. https://doi.org/10.1002/9781444317145.ch2. 
44. Pokrovsky O S, Karlsson J, Giesler R (2018) Freeze-thaw cycles of Arctic thaw ponds remove colloidal metals and generate low-molecular-weight organic matter. Biogeochemistry 137:321-336. https://doi.org/10.1007/s10533-018-0421-6

45. Pokrovsky O S, Manasypov R M, Kopysov S G, Krickov I V, Shirokova L S, Loiko S V, Lim A G, Kolesnichenko L G, Vorobyev S N, Kirpotin S N (2020) Impact of permafrost thaw and climate warming on riverine export fluxes of carbon, nutrients and metals in Western Siberia. Water 12:1817. https://doi.org/10.3390/w12061817

46. Pokrovsky O S, Manasypov R M, Loiko S V, Shirokova L S (2016) Organic and organo-mineral colloids in discontinuous permafrost zone. Geochim. Cosmochim Acta 188:1-20. https://doi.org/10.1016/j.gca.2016.05.035

47. Raudina T V, Loiko S V, Lim A G, Krickov I V, Shirokova L S, Istigechev G I, Kuzmina D M, Kulizhsky S P, Vorobyev S N, Pokrovsky O S (2017) Dissolved organic carbon and major and trace elements in peat porewater of sporadic, discontinuous, and continuous permafrost zones of western Siberia. Biogeosciences 14:3561-3584. https://doi.org/10.5194/bg-14-3561-2017

48. Raudina T V, Loiko S V, Kuzmina D M, Shirokova L S, Kulizhsky S P, Golovatskaya E A, Pokrovsky O S (2021) Colloidal organic carbon and trace elements in peat porewaters across a permafrost gradient in Western Siberia. Geoderma 390:114971. https://doi.org/10.1016/j.geoderma.2021.114971

49. Reeve A S, Siegel D I, Glaser P H (1996) Geochemical controls on peatland pore water from the Hudson Bay Lowland: a multivariate statistical approach. J. Hydrol. 181:285-304.

50. Ren J, Vanapalli S K (2020) Effect of freeze-thaw cycling on the soil-freezing characteristic curve of five Canadian soils. Vadose Zone J 19:e20039. https://doi.org/10.1002/vzj2.20039

51. Rezanezhad F, Price J S, Quinton W L, Lennartz B, Miloevic T, Van Cappellen P (2016) Structure of peat soils and implications for water storage, flow and solute transport: A review update for geochemists. Chem Geol 429:75-84. https://doi.org/10.1016/j.chemgeo.2016.03.010

52. Romanovsky V E, Smith S L, Christiansen H H (2010) Permafrost thermal state in the polar Northern Hemisphere during the international polar year 2007-2009: a synthesis. Permafr Periglac Process 21:106-116. https://doi.org/10.1002/ppp.689

53. Savenko A V, Savenko V S, Pokrovsky O S (2020) Phase fractionation of chemical elements during the formation of ice in fresh surface waters. Doklady Acad Sci Ser Earth Sci Geography 492(1):4854. https://doi.org/10.1134/S1028334X20050207

54. Schimel J P, Clein J S (1996) Microbial response to freeze-thaw cycles in tundra and taiga soils. Soil Biol Biochem 28:1061-1066. https://doi.org/10.1016/0038-0717(96)00083-1

55. Schwamborn G, Schirrmeister L, Frütsch F, Diekmann B (2012) Quartz weathering in freeze-thaw cycles: experiment and application to the El'gygytgyn Crater Lake record for tracing Siberian permafrost history. Geografiska Annaler: Series A, Physical Geography. 94:481-499. doi:10.1111/j.1468-0459.2012.00472.x

56. Shafique U, Anwar J, uz-Zaman W, Rehman R, Salman M, Dar A, Jamil N (2012) Forced migration of soluble and suspended materials by freezing front in aqueous systems. J Hydro-Environ Res 6:221- 
226. https://doi.org/10.1016/j.jher.2011.10.001

57. Sharma S, Szele Z, Schilling R, Munch J C, Schloter M (2006) Influence of freeze-thaw

58. stress on the structure and function of microbial communities and denitrifying populations in soil. Appl Environ Microbiol 72(3):2148-2154. https://doi.org/10.1128/AEM.72.3.2148-2154.2006

59. Six J, Bossuyt H, Degryze S, Denef K (2004) A history of research on the link between (micro) aggregates, soil biota, and soil organic matter dynamics. Soil Tillage Res 79 (1). https://doi.org/731. 10.1016/j.still.2004.03.008

60. Smerdon B D, Mendoza C A (2010) Hysteretic freezing characteristics of riparian peatlands in the Western Boreal Forest of Canada. Hydrol Process 24(8):1027-1038. https://doi.org/10.1002/hyp.7544

61. Spencer R G M, Bolton L, Baker A (2007) Freeze/thaw and pH effects on freshwater dissolved organic matter fluorescence and absorbance properties from a number of UK locations. Water Res 41:2941-2950. https://doi.org/10.1016/j.watres.2007.04.012

62. Tierney G L, Fahey T J, Groffman P M, Hardy J P, Fitzhugh R D, Driscoll C T (2001) Soil freezing alters fine root dynamics in a northern hardwood forest. Biogeochemistry 56:175-190. https://doi.org/10.1023/A:1013072519889

63. Vestgarden L S, Austnes K (2009) Effects of freeze-thaw on $C$ and $N$ release from soils below different vegetation in a montane system: a laboratory experiment. Glob Change Biol 15:876-887. https://doi.org/10.1111/j.1365-2486.2008.01722.x

64. Xiao L, Zhang Yang Li P, Xu G, Shi P, Zhang Yi (2019) Effects of freeze-thaw cycles on aggregateassociated organic carbon and glomalin-related soil protein in natural-succession grassland and Chinese pine forest on the Loess Plateau. Geoderma 334:1-8. https://doi.org/10.1016/j.geoderma.2018.07.043

65. Xue S, Wen Y, Hui X, Zhang L, Zhang Z, Wang J, Zhang Y (2015) The migration and transformation of dissolved organic matter during the freezing processes of water. J Environ Sci 27:168-178. https://doi.org/10.1016/j.jes.2014.05.035

66. Yeghicheyan D, Bossy C, Bouhnik Le Coz M, Douchet Ch, Granier G, Heimburger A, Lacan F, Lanzanova A, Rousseau T C C, Seidel J-L, Tharaud M, Candaudap F, Chmeleff J, Cloquet C, Delpoux S, Labatut M, Losno R, Pradoux C, Sivry Y, Sonke J E (2013) A compilation of silicon, rare earth element and twenty-one other trace element concentrations in the natural river water Reference Material SLRS-5 (NRC-CNRC). Geostand Geoanal Res 37:449-467. https://doi:10.1111/j.1751908X.2013.00232.x

67. Yu X, Zou Y, Jiang M, Lu X, Wang G (2011) Response of soil constituents to freeze-thaw cycles in wetland soil solution. Soil Biol Biochem 43:1308-1320. https://doi.org/10.1016/j.soilbio.2011.03.002

\section{Figures}




\section{Figure 1}

Total bacterial count (A), DOC (B), P (C), Ca (D), Fe $€, A l(F), \mathrm{Zn}(\mathrm{G}), \mathrm{Ni}(\mathrm{H})$ and $\mathrm{La}(\mathrm{I})$ distribution in the peat core before (open circles) and after (solid diamonds) bi-directional freezing/thawing experiment on three sections $(15-50,50-70$ and $70-95 \mathrm{~cm})$ of a peat core. Note that experiment with bacterial count was run in 3 independent replicates.

\section{Figure 2}

A: Depth-integrated $(20-90 \mathrm{~cm})$ median of element concentration ratio in peat pore waters after freeze/thaw experiment to that in the initial peat core, prior to freezing. B: Median ratio for the permafrost (40-90 cm) horizon. Error bars account for sizable variation of element concentrations over the full core depth (s.d. of $n=14$ layers). C: Average ratio of the maxima of element concentration after experimental freeze/thaw to that in the native peat and ice (prior freezing). The error bars reflect the s.d. of three sections of the peat core.
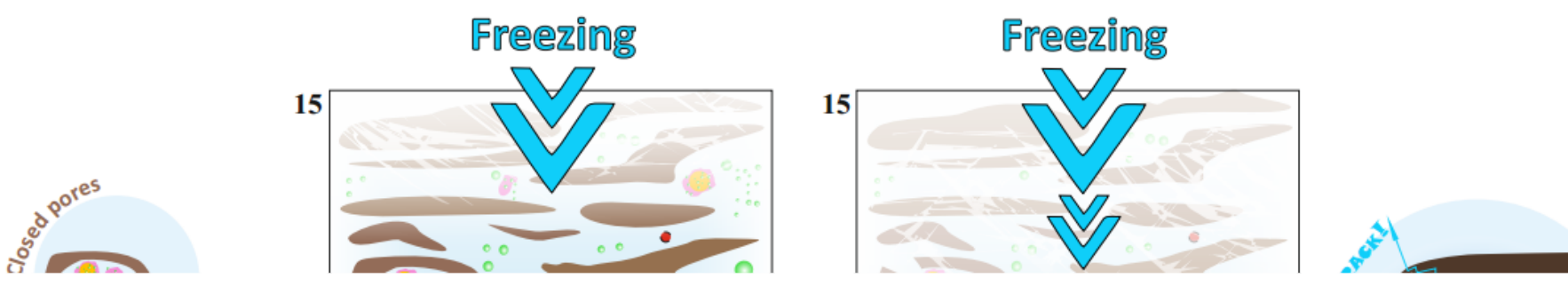

Figure 3 
Cartoon of processes controlling bacteria, DOC and trace element partitioning during bidirectional freezing of a peat core. Peat cores with pores of water and ice are subjected to freezing from both sides resulting in a two freezing front migration. DOC, colloids and bacteria concentrate in the layer where the two freezing fronts meet. Upon thawing of the frozen core, there is reversible dissolution of organomineral coagulates. Mechanisms of porewater enrichment in elements after freeze/thaw experiment are: i) opening of isolated peat pores containing DOC, bacteria and colloids; ii) release of peat grain components $(\mathrm{OC}, \mathrm{P}, \mathrm{K}, \mathrm{Cu}, \mathrm{Cd}, \mathrm{Ni})$ into the fluid, especially in the bottom part of the core.

\section{Supplementary Files}

This is a list of supplementary files associated with this preprint. Click to download.

- FreezingpeatforESPRDecember2021SupplementONLY.docx 